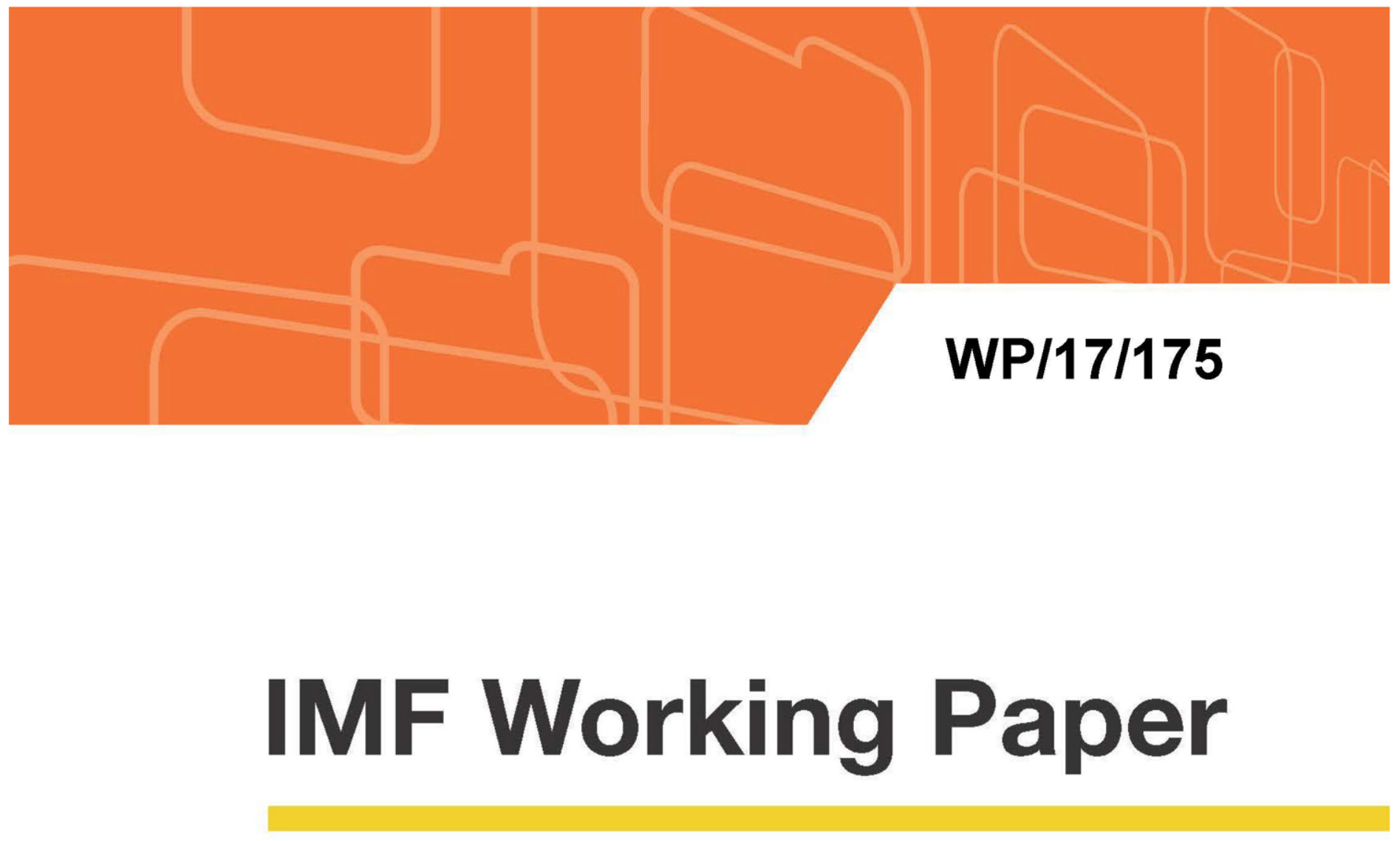

\title{
Bank Consolidation, Efficiency, and Profitability in Italy
}

by Anke Weber

IMF Working Papers describe research in progress by the author(s) and are published to elicit comments and to encourage debate. The views expressed in IMF Working Papers are those of the author(s) and do not necessarily represent the views of the IMF, its Executive Board, or IMF management.

I N T E R N A T I O N A L M O N E T A R Y F U N D 


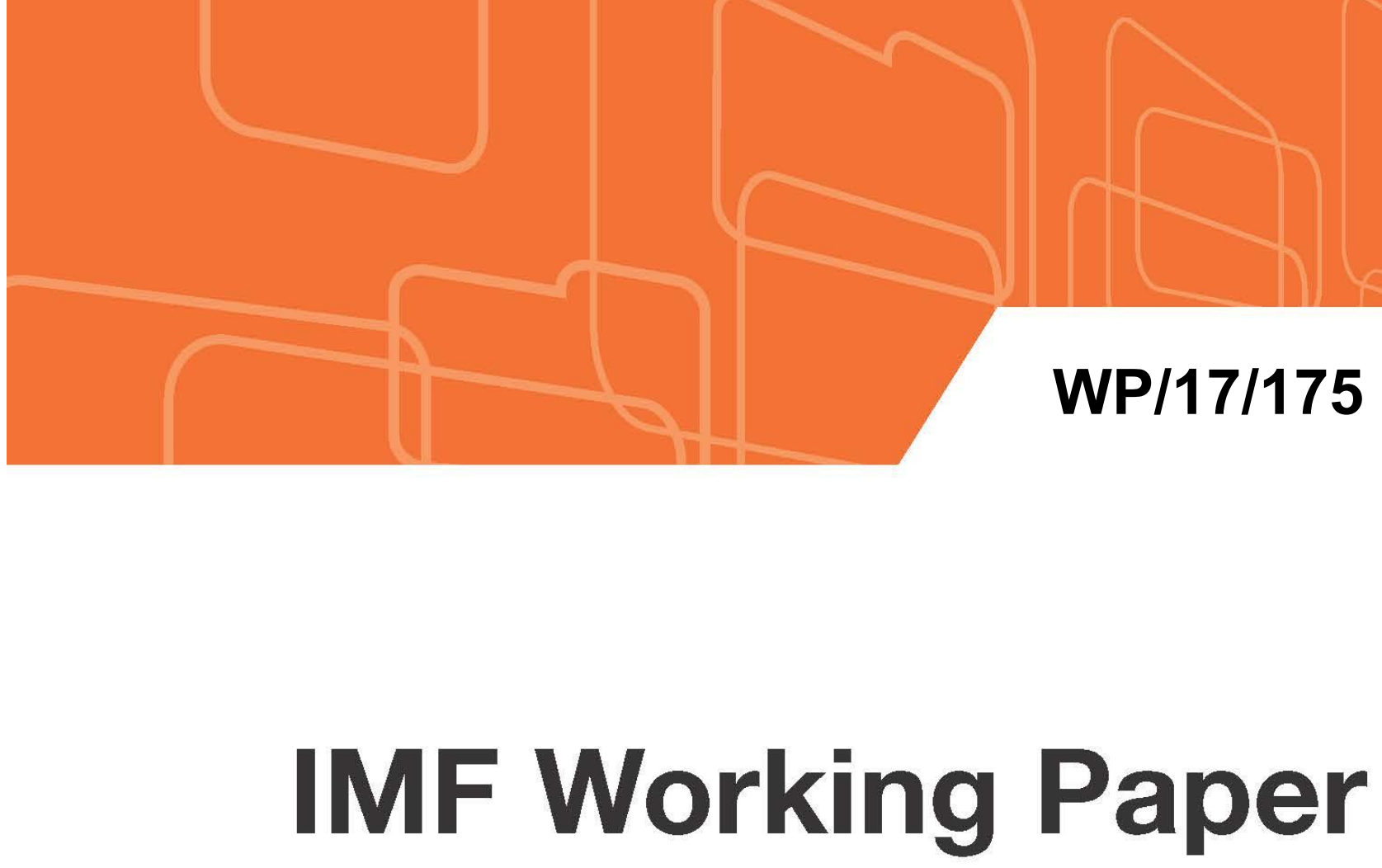

\section{Bank Consolidation, Efficiency, and Profitability in Italy}

by Anke Weber

IMF Working Papers describe research in progress by the author(s) and are published to elicit comments and to encourage debate. The views expressed in IMF Working Papers are those of the author(s) and do not necessarily represent the views of the IMF, its Executive Board, or IMF management.

I N T E R N A T I O N A L M O N 


\title{
IMF Working Paper
}

European Department

\section{Bank Consolidation, Efficiency, and Profitability in Italy ${ }^{1}$ \\ Prepared by Anke Weber}

Authorized for distribution by Rishi Goyal

July 2017

IMF Working Papers describe research in progress by the author(s) and are published to elicit comments and to encourage debate. The views expressed in IMF Working Papers are those of the author(s) and do not necessarily represent the views of the IMF, its Executive Board, or IMF management.

\begin{abstract}
This paper examines the case for efficiency-driven banking sector consolidation in Italy, evaluates its potential effects on profitability, and discusses policy options to facilitate a consolidation process that is as effective as possible. A bottom-up analysis of 386 Italian banks suggests that while profitability is expected to improve as the economy gradually recovers, operational efficiency gains are nonetheless needed to restore large parts of the banking system to healthy profitability. Banking system consolidation can play a role in facilitating such efficiency gains, but its effectiveness is likely to be most as part of a comprehensive strategy that includes complementary reforms to clean up bank balance sheets. Cross-country experience indicates that efficiency gains are more likely to follow consolidations where careful viability analyses are conducted of the synergies and operational improvements that can be achieved.
\end{abstract}

JEL Classification Numbers: G18, G28.

Keywords: banks, bank consolidation, profitability.

Author's E-Mail Address: aweber@imf.org

\footnotetext{
${ }^{1}$ I am grateful to staff from the Bank of Italy and Italian Ministry of Economy and Finance, Tam Bayoumi, Nombulelo Braiton, John Caparusso, Enrica Detragiache, Jose Garrido, Rishi Goyal, Phakawa Jeasakul, Mitsuru Katagiri, Lucy Liu, Dermot Monaghan and Hiroko Oura for helpful comments and suggestions.
} 
I. Introduction $\underline{3}$

II. THE CASE FOR MORE BANKING SECTOR EFFICIENCY IN ITALY

III. How much could bank profitability increase from greater cost efficiency? .$\underline{5}$

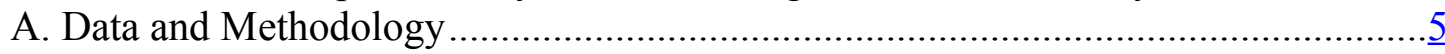

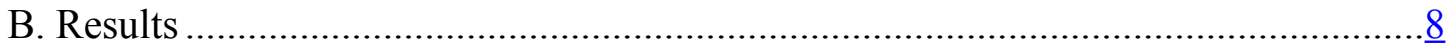

IV. Is there Room for Consolidation to Achieve Efficiency Gains? .....................................

V. How can the consolidation process that is ongoing in Italy be made as successful as

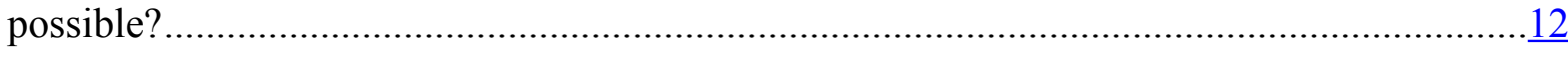

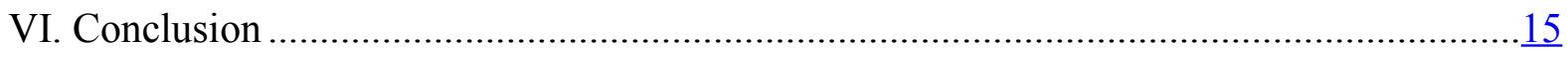

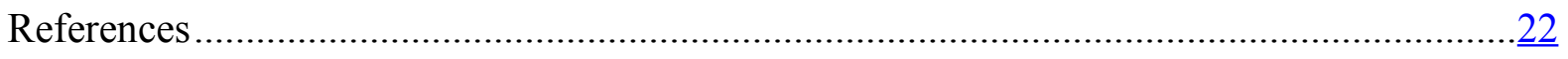

Table

1. Overview of Literature: Effects of M\&As on Efficiency, Competition, and Credit Flows. 20

Figures

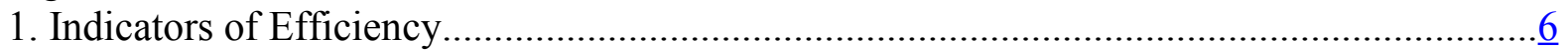

2. Profitability and Efficiency Ratios across Italian Banks in 2015 .................................

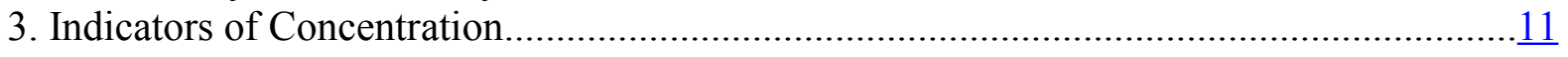

4. Mergers and Acquisitions in the Euro Area and Italy ................................................12

Boxes

1. Recent Reforms to Support Banking System Consolidation ........................................17

2. The Spanish Experience: Consolidation of Savings Banks .........................................18

3. Legal Aspects of Cross-Border M\&As in the EU ..................................................19

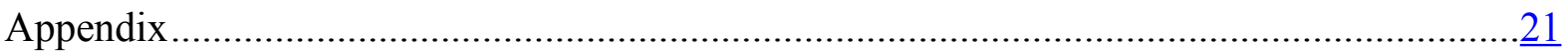




\section{INTRODUCTION}

The Italian banking system suffers from weak profitability and generally poor asset quality. ${ }^{2}$, The return on equity (RoE) of Italian banks is among the lowest in the EU. The weakness in profitability reflects several cyclical, structural, and legacy factors. Cyclical challenges are linked to difficulties in increasing revenues in a low nominal growth and low interest rate environment. This is especially so for a system that devotes a larger part of its assets to lending than in other countries. Structural factors relate to banking sector efficiency. Relatively high operating costs compared to many other European countries play a significant role in explaining Italian banks' relatively low profitability (Albertazzi and others, 2016, IMF, 2017). Legacy factors include notable asset quality challengesnonperforming loans (NPLs) are very high

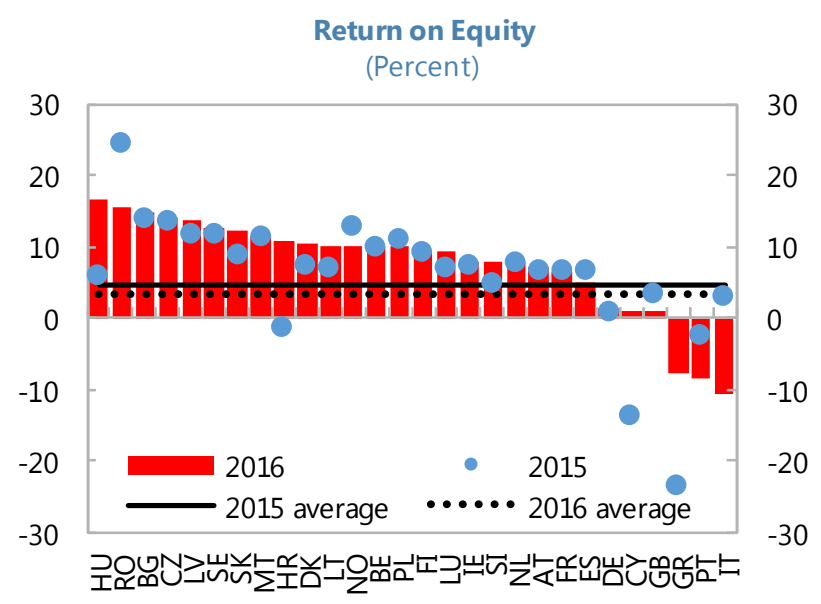
at around 21 percent of GDP, although they have declined marginally recently - and the associated need for provisioning. ${ }^{3}$

\section{reforms. Measures have aimed to tackle asset quality problems, including through changes to the insolvency and enforcement framework and state guarantees on certain types of NPL securities (Garrido and others, 2016; and Garrido, 2016). To spur consolidation of Italy's fragmented banking sector - there were around 400 consolidated banking groups and about 200 subsidiaries in end-2016 - the authorities passed legislation to transform the governance structure of the larger cooperative (popolare) banks}

Cognizant of these challenges, the Italian authorities have legislated a number of

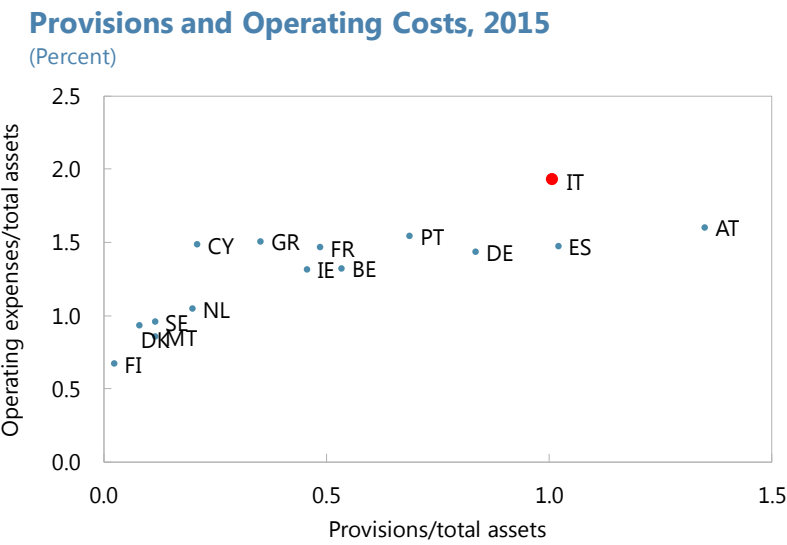

Sources: European Central Bank

\footnotetext{
${ }^{2}$ For cross-country comparisons, the paper uses data from the European Banking Authority (EBA) risk dashboard in several charts. These data are based on 198 European banks, 15 of which are Italian. Several charts also rely on data from the European Central Bank's consolidated banking database. Data are based on domestically controlled banks, which have been consolidated across borders and sectors. There are some important caveats regarding these data, especially when making comparisons between countries as there are differences in the structure of the banking sector across the European Union that should be taken into consideration. Also, country-level information may differ from that published in individual countries' reports because of differences in the reporting populations.
}

${ }^{3}$ There were substantial write-downs in 2016. 
(March 2015) and smaller cooperative (mutual) banks (February 2016) and to change the governance of foundations (April 2015) (Box 1). The March 2015 legislation required the 10 largest popolare banks (those with assets exceeding $€ 8$ billion) to be transformed into joint stock companies by end-2016. ${ }^{4}$ As a result of these reforms, one merger has been completed so far-between Banco Popolare and Banca Popolare di Milano in 2016, creating the third largest banking group in Italy. The mutual bank reform requires the 355 smaller cooperative banks to consolidate under joint-stock (holding) companies with at least $€ 1$ billion in equity in 18 months starting November 2016 (the time the secondary legislation was passed). Merger and acquisition (M\&A) activity among mutual banks is expected to accelerate sharply over the next year. Once fully implemented, these reforms are expected to result in a more concentrated banking sector over the course of the next few years, with around 140 consolidated banking groups.

This paper examines the case for banking sector consolidation in Italy, evaluates the potential effects on profitability, and discusses policy options to facilitate a consolidation process that is as effective as possible. It is structured as follows. Section II looks critically at whether there is a case for efficiency gains in Italy by comparing Italian banks both to peers within Europe as well as looking at heterogeneity among banks within the country. Section III investigates potential gains in profitability from greater cost efficiency. Section IV examines whether bank consolidation can play a useful role in achieving the needed efficiency gains and takes a critical look at the literature on bank consolidation and what lessons can be learned. The last section examines how the ongoing process of consolidation in Italy can be made as efficient as possible to maximize potential benefits. Section V concludes.

\section{THE CASE FOR MORE BANKING SECTOR EFFICIENCY IN ITALY}

The profitability of Italian banks is hindered by their relative cost inefficiency (Figure 1 and text figure). ${ }^{5}$

- Italian banks have among the highest structural costs among advanced European countries when costs are standardized by total assets. Italian banks spent 2 percent of their assets as operating expenses in 2015 , which is significantly above the spending in the other large economies in the euro area, Germany, France, and Spain. ${ }^{6}$ The high costs are due to several factors including Italian banks' business models (they devote a larger part of their assets to lending to households and firms than in other countries), the

\footnotetext{
${ }^{4}$ As of Q2 2016, there were 29 BPs in total. The 10 largest BPs with assets above $€ 8$ billion account for about 90 percent of the total assets of BPs. The original deadline for this process to be completed was end-2016 and eight of the ten largest popolare banks already underwent the transformation to joint stock companies.

However, the reform is currently on hold owing to successful challenges in court, related to compensation of dissenting investors.

${ }^{5}$ We rely on simple measures of efficiency, such as cost-to-income ratios and RoEs. A more sophisticated approach would perform an efficiency frontier analysis and compute the distance of each bank from the frontier as a measure of its (in)efficiency.

${ }^{6}$ This results also holds for 2014. For an average over 2008-14, Italy has the highest costs in the euro area, along with Austria, Slovenia and Slovakia.
} 
relatively high number of branches per capita, and personnel expenses. When costs are standardized by total operating income, Italian banks are comparable to other large economies such as France and Germany. Nonetheless, their cost-to-income ratios are significantly above the EU median.

- Some progress has been made in addressing some of these inefficiencies. Since the beginning of the crisis, there has been some reduction in branches and headcounts in Italy. The number of branches and employees at Italian banks have decreased by about 10 percent between 2008 and 2015 .

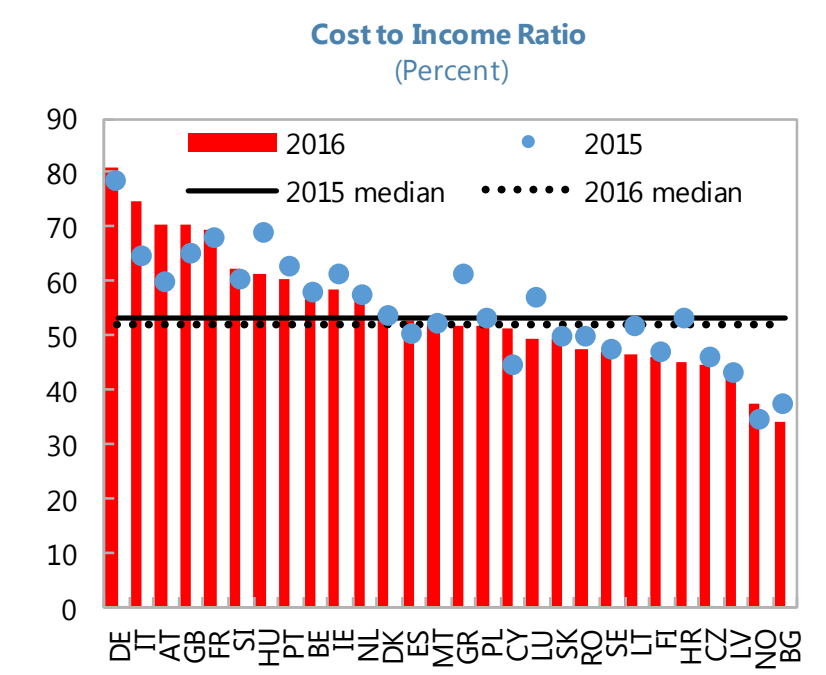

Source: Eu ropean Banking Authority, Risk Dashboard Q4 2015/1€

There is a significant degree of heterogeneity within the Italian banking system. While some banks in the system have above EU average profitability ratios and lower cost-toincome ratios than the EU average, other parts are lagging behind (Figure 2 and Appendix Figure A1). Both large and small banks suffer from low profitability and high costs - there is no strong correlation between efficiency and size. But there is a large dispersion within types of banks with some mutual and popolare banks enjoying healthy levels of profitability and cost efficiency while others are weak. The large dispersion in profitability and cost efficiency among banks of similar sizes often indicates room for efficiency improvement (Amel and others, 2002).

\section{HOW MUCH COULD BANK PROFITABILITY INCREASE FROM GREATER COST EFFICIENCY?}

\section{A. Data and Methodology}

This section calculates profitability for 386 Italian credit institutions for which data from S\&P Global Market Intelligence are available. ${ }^{7}$ These banks account for about 92 percent of system-wide assets. 2015 annual data from S\&P Global are used ${ }^{8}$ The analysis builds on Jobst and Weber (2016), which had performed similar calculations for the largest 15 Italian banks.

\footnotetext{
${ }^{7}$ We use information on the names of less significant institutions (LSIs) provided by the Bank of Italy (2016) to match bank data from S\&P Global and ensure that we are not including subsidiaries or foreign banks. According to BoI (2016), there were 462 LSIs in 2016 of which we cover 372 . We have data on all 14 significant institutions.

${ }^{8}$ Specifically, the following variables from S\&P Global are used or constructed: net interest income/average assets, cost of funds, cost-income ratio, Capital Adequacy Ratio or CAR defined as ((Tier 1 capital +Tier 2 capital)/total risk-weighted assets), credit risk-weighted assets, fee and commission income/operating income, total gross loans, loan loss provisions/operating income, and net operating income.
} 


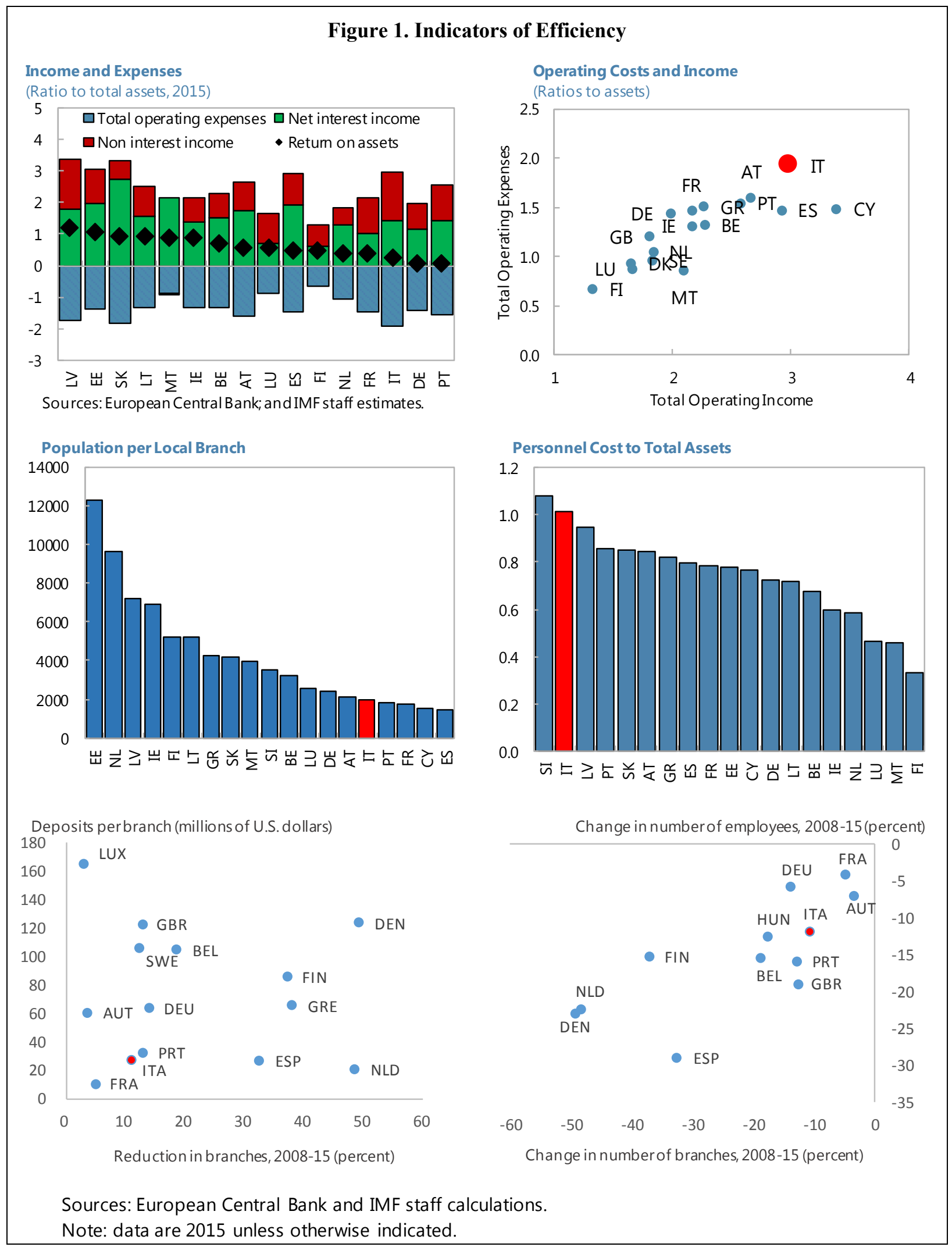

CInternational Monetary Fund. Not for Redistribution 


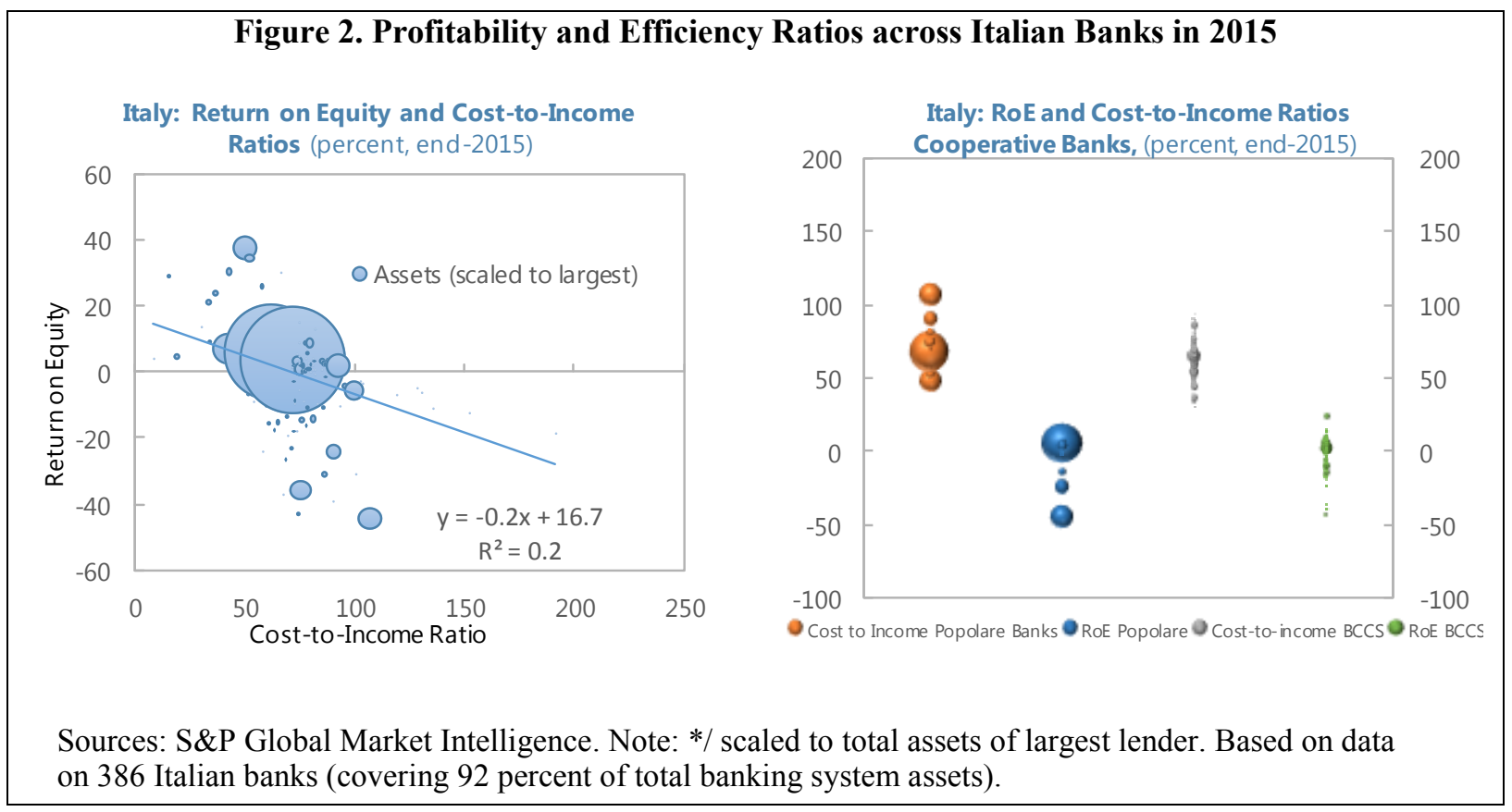

Profitability measure. As described in more detail in Jobst and Weber (2016), for each of the banks, profitability is calculated as the net return on equity $(\mathrm{RoE})^{9}$ based on net interest margins (NIMs), commissions/fee income, and operating expenses in the reported profit and loss statement of each bank, after accounting for firm-specific capitalization. ${ }^{10}$ The net RoE in year $t$ is thus calculated as

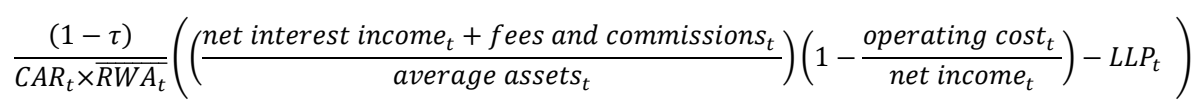

where $\tau$ is the tax rate and LLP denotes reported provisioning.

Scenario analysis. An important question is whether the current low levels of profitability in Italy are a cyclical problem, which will remedy itself once the economy recovers or are due to structural issues, which would call for more deep rooted reforms. Two alternative scenarios are considered: (i) cyclical recovery. This scenario assumes that the cyclical recovery that is underway will continue in line with the Spring 2017 WEO projections ${ }^{11}$. In line with IMF (2016), net interest income is assumed to improve as the benchmark short-term interest rate rises by 50 basis points. ${ }^{12}$ At the same time, provision expenses decline as the

\footnotetext{
9 The term "return on equity" is used as a generic reference to leveraged income, with equity referring to CAR.

${ }^{10}$ A tax rate of 35 percent is assumed for all banks.

${ }^{11}$ Average growth is projected to be below 1 percent during the period 2017-22.

${ }^{12}$ Using the historical elasticity of the NIM for Italy (see Elliott and others, 2016), the NIM is assumed to improve by 25 basis points.
} 
economic recovery improves borrower credit quality. ${ }^{13}$ (ii) Structural reform. This scenario assumes that the cost-to-income ratio for each of the banks in the sample declines to the median cost-to-income ratio of Italian banks in our sample that enjoyed healthy levels of profitability (above 10 percent) in 2015, with the exception of those banks whose cost-toincome ratios are already below that benchmark. ${ }^{14}$

Banks are distributed among three buckets for each of these scenarios: those with RoEs above 10 percent (healthy), between 8-10 percent (challenged) and below 8 percent (weak). The motivation for this choice of threshold is twofold. First, it follows the analysis in IMF (2016, 2017). IMF $(2016,2017)$ uses these thresholds for a larger sample of European countries and links it to the cost of equity capital, which is found to lie between 8 and 10 percent. ${ }^{15}$ If banks consistently earn less than their cost of equity, they will face considerable challenges in raising private capital and could again become undercapitalized after an unexpected loss or during a broader downturn in their business. Thus, ensuring that banks are able to earn an adequate rate of return on equity is important for maintaining a vibrant and healthy banking system. Second, Mohaddes and others (2017) show that there exists a tipping point for real and nominal GDP growth in Italy above which the ratio of nonperforming loans (NPLs) to total loans falls significantly. The threshold is estimated 3 percent for nominal GDP growth (or 1.2 percent for real GDP growth). They argue that one of the channels through which higher GDP growth impacts NPLs is through higher profitability, which enables banks to raise capital buffers and accelerate the cleanup of their balance sheets. Interestingly, in years, in which the economy was growing just above 3 percent in nominal terms, a return on equity of above 10 percent was observed.

\section{B. Results}

\section{Addressing cost efficiency is key to significantly improving profitability, alongside measures to clean up bank balance sheets. According to the latest data from S\&P Global, the vast majority of Italian banks are suffering from weak profitability.}

- While a continuation of the current modest cyclical recovery will strengthen profitability of the system, it is unlikely to be sufficient to restore large parts of the system to healthy profitability. The banking system will remain vulnerable to adverse shocks.

\footnotetext{
${ }^{13}$ More specifically, this scenario assumes that, based on the analysis in Jobst and Weber (2016), provision expenses (in percent of total operating income) halve for each bank within the next five years, assuming the recovery proceeds as expected in the Spring 2017 WEO submissions.

14 This cost-to-income ratio would be 52 percent, approximately the same as the EU median cost-to-income over the last three years based on the EBA sample.

15 This estimate is based on a survey in the EBA's December 2015 risk assessment report, in which 49 percent of respondents estimated a cost of equity between 8 and 10 percent, 27 percent in the range of 10 to 12 percent, and 14 percent above 12 percent. On a blended basis, the average cost of equity is above 9 percent, based on banking authority estimates (see also IMF, 2016).
} 
- Enhancing operational efficiency and aligning cost-to-income ratios to the best performing Italian banks or the European median will have a significant impact on profitability. ${ }^{16}$ However, even in this scenario, more than 50 percent of the banking system is still challenged or weak, indicating that other factors, which are dragging down profitability, such as the high stock of legacy NPL assets, also need to be addressed.

- To secure the effectiveness of the recent NPL guidance by the

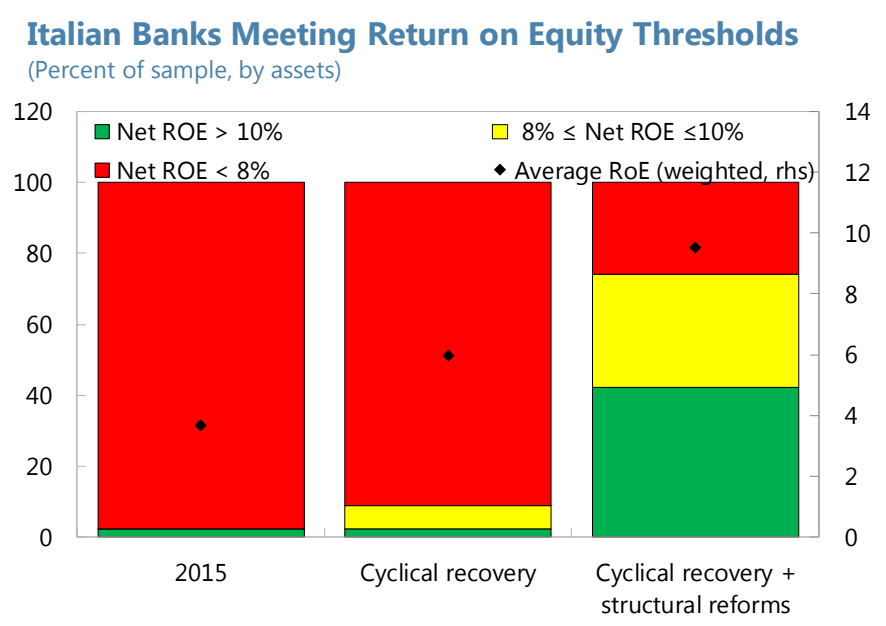

Sources: S\&P Global Market Intelligence and IMF Staff Calculations Single Supervisory Mechanism (SSM), supervisors need to ensure NPL reduction strategies and targets are ambitious and credible. Sizeable NPL sales are planned in the coming year, which need to be implemented and backed up by strong and credible restructuring plans. Complementary measures include further advancing insolvency and enforcement reforms (beyond recent policy measures), and the facilitation of distressed debt markets (Garrido and others, 2016; Garrido, 2016; Jobst and Weber, 2016).

- Beyond that, further cuts in operational costs may be needed for the remaining banks with weak profitability metrics, accounting for about one-fifth of the system. Effective use should be made of the resolution framework to safeguard financial stability and enhance economic efficiency.

\section{IS THERE ROOM FOR CONSOLIDATION TO ACHIEVE EFFICIENCY GAINS?}

\section{The Italian banking system is fragmented (Figure 3).}

- Italy had 635 credit firms as of Q2 2016, of which more than half are small cooperative (mutual) banks. While this number has decreased significantly since the 1990s, it is still high compared to some other large euro area countries (e.g., Spain).

- Measures of market concentration point to lower concentration levels than in most other euro area countries. The market shares of the five largest credit institutions account for about 40 percent. At the same time the Herfindahl index, a commonly accepted measure of market concentration, is among the lowest in euro area countries. Market measures of concentration are closely related to the size of the banking system and credit market.

\footnotetext{
${ }^{16}$ Banks will have to adapt to the digitalization of financial transactions (together with the penetration of online/mobile banking), that could change retail banking business substantially. Nordic banks are a good example of successfully focusing towards electronic solutions and innovative services, reducing branches, and improving cost efficiency.
} 
While according to these indicators the Italian banking system is more concentrated than the German one, there is scope to increase concentration as has been done in Spain since 2008 (see also Box 2).

At first glance, there thus appears to be some room for efficiency-driven consolidation. Consolidation of banks or the reduction in the overall number can be achieved through mergers and acquisitions (M\&As, domestically and across borders). ${ }^{17}$ The relatively low level of concentration and signs of overcapacity suggest that there is room for M\&As, accompanied by downsizing and cost cutting that could generate efficiency gains, while remaining well within the so-called "too-big-to-fail" problem. A simple scatter plot of concentration and efficiency indices also indicates that banks

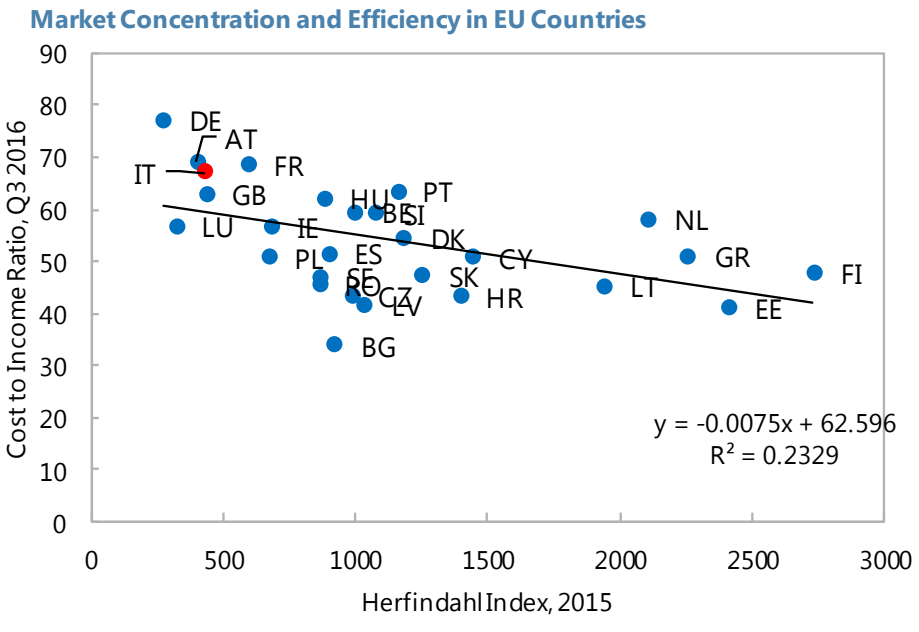

Sources: European Central Bank; Eu ropean Banking Authority operating in less concentrated markets tend to be less efficient and, hence, less profitable. ${ }^{18}$ This is confirmed by available empirical evidence (Kok and others, 2015). It should also be noted that resolution and orderly exits where necessary (implemented in accordance with the Bank Recovery and Resolution Directive) could eventually force inefficient intermediaries out of the market, thus potentially achieving efficiency gains similar to those attainable through efficient consolidations.

\section{However, consolidation through M\&As should not be seen as a panacea to deal with banking sector problems. In theory, efficiency gains from consolidation can be achieved} through reduction in average costs, exploitation of economies of scale, and improvement in managerial efficiency. However, the existing literature points to mixed effects of bank consolidation on efficiency, financial stability and credit flows (Table 1). Many studies fail to find significant evidence that M\&As allow banks to exploit economies of scale and scope, and generate cost savings especially for domestic transactions, while cross-border M\&As fare somewhat better in enhancing efficiency. This is often explained by obstacles to costcutting such as strict labor laws. There is also some evidence that consolidation may harm

\footnotetext{
${ }^{17}$ Two mid-size lenders in the Veneto region were recently liquidated and Intesa, Italy's second largest bank, acquired some of their assets and liabilities. Moreover, the four small banks that were resolved in November 2015 were recently sold to two popolare banks.

${ }^{18}$ Cost-to-income ratios from EBA are used as more recent data are available. Replicating the chart with 2015 ECB data on cost-to-assets ratios also shows a negative relationship.
} 
small business lending, at least in the short-term, highlighting the importance of developing alternative sources of financing to traditional bank lending. ${ }^{19}$

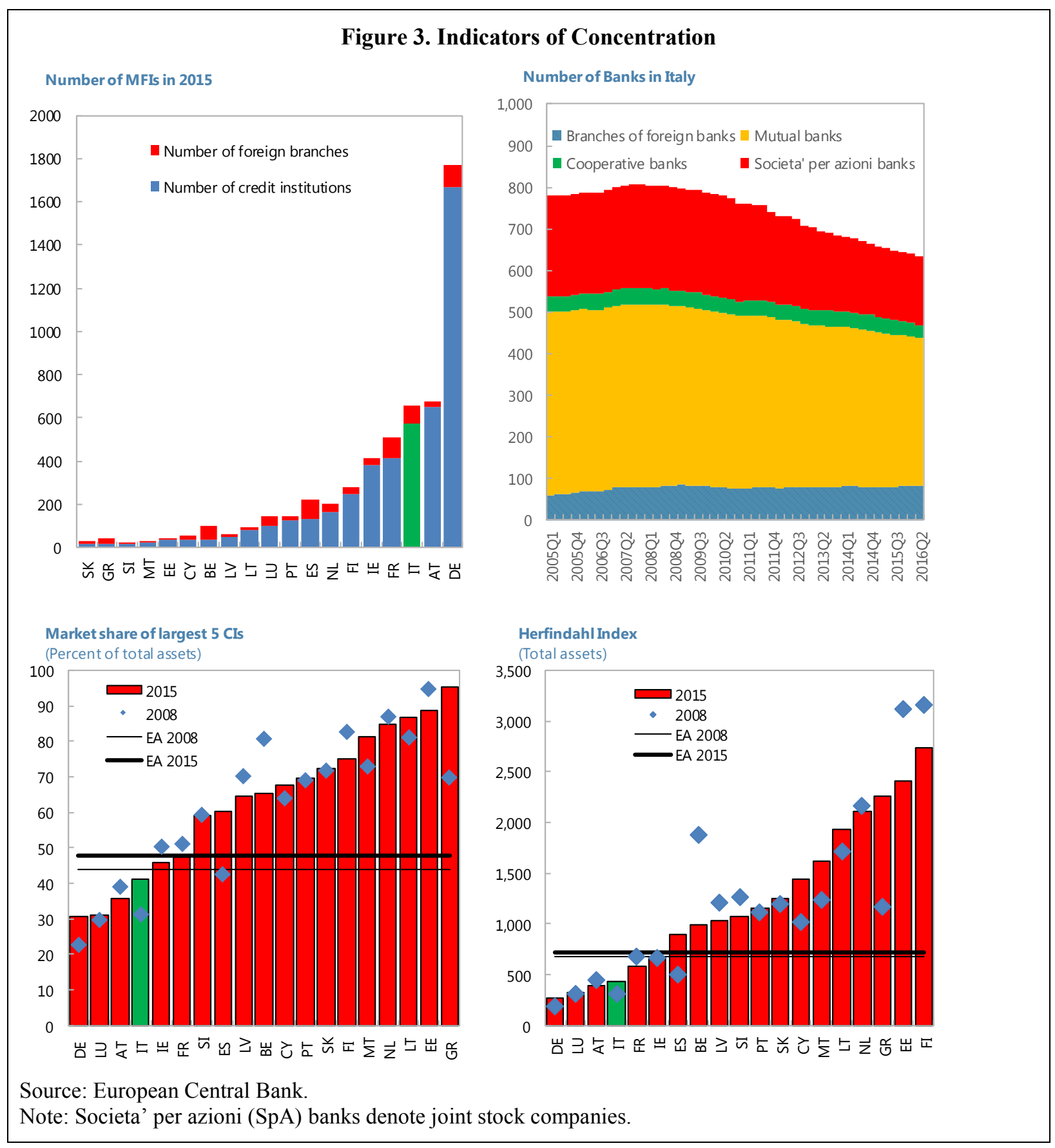

\footnotetext{
${ }^{19}$ The authorities have recently passed a "Finance for Growth" package, a series of measures in order to open up financing channels as alternatives to banks.
} 
It is also unclear whether the merger wave that was seen in the past can be repeated. Compared to pre-crisis trends, total M\&A activity has declined significantly in 2013-17 both in terms of the number of deals and especially in terms of value. This is true for Italy and the euro area. Most transactions have been taking place domestically. With the financial crisis, the share of cross-border deals (between banks in the euro area) declined even further in the EA and Italy (Figure 4).

It is thus essential that $M \& A s$ are part of a comprehensive strategy to address banking sector problems. Profitability gains cannot come solely from M\&As but other measures are also needed, such as growth-enhancing structural reforms as well as active resolution measures for NPLs. Some large banks also need to rationalize their operations and restructure their business models, with UniCredit, Italy's largest bank already starting to take those steps recently with a large capital raising plan and efforts to reduce the stock of NPLs. It is to be seen whether other banks can follow suit.

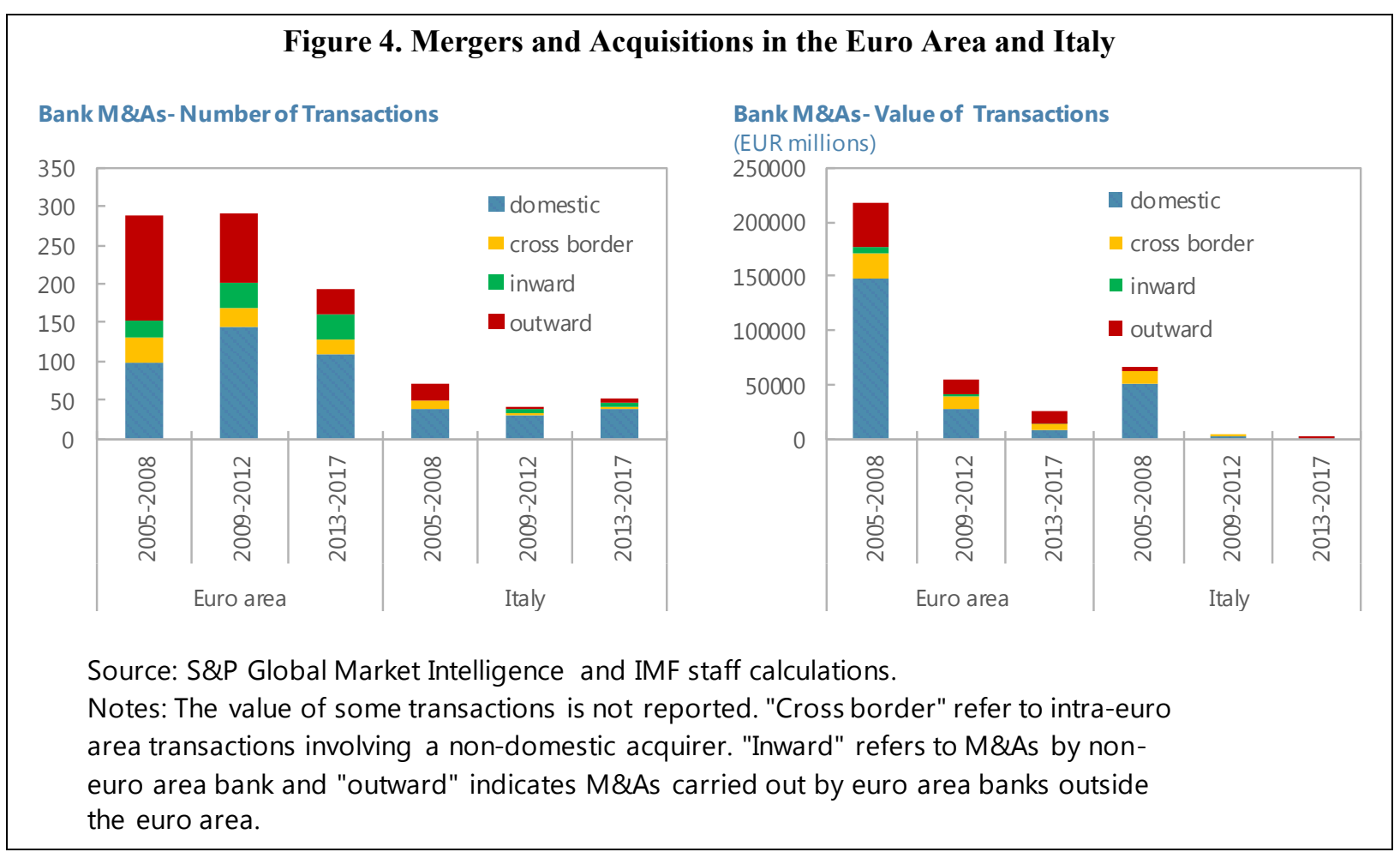

\section{HOW CAN THE CONSOLIDATION PROCESS THAT IS ONGOING IN ITALY BE MADE AS SUCCESSFUL AS POSSIBLE?}

While the above-mentioned reforms open the way to reforms of governance and consolidation, it cannot be taken for granted that they will necessarily result in a stronger and more efficient banking system that is able to support the economic recovery. In particular, it is far from clear that essential cost cutting will follow that could restore important parts of the banking system to healthy profitability. Experiences from other countries highlight the importance of enhancing governance and tackling remaining vested 
interests as part of the consolidation process, strengthening supervisory oversight, taking prompt corrective action when needed, and addressing structural rigidities that could limit efficiency gains (Box 2).

To reap as many of the efficiency-enhancing benefits of consolidation as possible, consideration could thus be given to the following actions:

- Supervisory encouragement and oversight of consolidation. It is not clear how it will be ensured that the ongoing reforms to facilitate consolidation will result in efficiency gains. This is especially true for the case of the mutual banks, where coordination and risk sharing are slated to occur, but it is unclear how cost cutting would be achieved in practice. Cases where mergers of banks in difficulties result in larger banks that eventually require state support should be avoided. It is therefore important for the supervisor to take a proactive stance. This should include rigorous challenge of:

- Capital adequacy. To ensure that the emerging banks have adequate capital - this requires either an asset quality review of the existing banks or the new emerging banks. Given that a consolidation project could fail if significant capital shortfalls are identified, the diagnostic should be done ex ante, and it will also ensure that all small banks are adequately capitalized (not just those that have consolidated).

- New bank business models. To ensure that the entity has sufficient income generating capacity to build capital through retained earnings, even in a downside scenario. This should involve rigorous challenge of business lines in terms of credibility of income and cost assumptions as well as their ability to withstand negative shocks to liquidity and asset quality.

- New bank consolidation programs. To ensure that each bank has granular, ambitious and credible targets related to centralizing of risk management (the system of policies/processes/controls) and IT as well as branch/staff rationalization and will be implemented effectively.

- Governance arrangements. Through robust challenge of new governance structures, including that boards and executive committees are staffed with well qualified and experienced people, that boards contain highly experienced and assertive independent directors.

- Address structural rigidities limiting efficiency gains. Although the recent labor market reforms (Jobs Act) should increase labor market flexibility gradually over time, banks are likely to find it difficult to reduce their workforce, as the Jobs Act applies to new labor contracts. This results very often in costly early retirement packages. ${ }^{20}$ Considering this, the Italian authorities have allocated $€ 500$ million over the next three years to help commercial banks finance early retirement schemes. Notwithstanding these

\footnotetext{
${ }^{20}$ For instance, according to the banking trade union, FABI, 16,000 banking jobs will be cut by 2020 of which 9,000 are expected to be early retirement.
} 
rigidities, banks are responsible for delivering on cost rationalization plans, including to achieve ambitious targets on labor cost cutting.

- Resolve outstanding governance issues in the system and challenge vested interests. The experience from Spain shows the importance of strengthening governance as part of the consolidation process as well as prompt corrective action when needed (Box 2).

- Some papers point to a significant role of vested interests in Italian banks with detrimental effects on efficiency and loan quality. Infante and Piazza (2014) find robust evidence that politically connected firms have benefitted from lower interest rates when the political connection is at the local level (town councils) and show that this effect is generally stronger when politically connected firms borrow from politically influenced banks (identified as banks with politicians on their boards). These results suggest that some form of collusion may take place between local loan officers and politicians. Carretta and others (2011) show that politically connected cooperative banks, in which politicians have executive roles in the board of directors, display higher net interest revenues, lower quality of the loan portfolio and lower efficiency relative to a control group of non-connected counterparts.

- Legislative gaps in Italy's implementation of the EU fit and proper rules for bank management (from the EU Capital Requirements Directive or the so-called CRD-IV) should be closed. When implemented, the 2015 EBA and 2016 ECB guidance relating to fit and proper assessments can be applied in full. Consideration could also be given to a deep review of bank governance that contains rigorous fit and proper requirements, including: composition of boards (number of board members and number of independents), competence of board members, applying time limits to board participation (e.g., no more than 5-7 years), structure of board sub-committees including requiring independent board members to chair, and a thematic review of related party lending.

- A number of improvements are planned or being implemented. At the national level, the adoption of fit and proper requirements is needed and a draft decree was prepared to that end, while the thematic review of related party lending is in place. At the SSM level, the ECB is adopting evaluation criteria on the composition, competence, and political independence of board members.

\section{There may also be a role for policies at the $\mathrm{EU}$ level to facilitate more cross border consolidation.}

- Cross border M\&As could be beneficial for several reasons. First, if consolidation were to take place at the European level, it could reduce cross-border fragmentation and overcome the domestic or home bias of the overwhelming majority of banks. The existence of more banks with a pan-European outlook could enhance risk pooling and help weaken the link between the macroeconomic risks existing in each country and the stability of its banking system, adding robustness to the monetary and banking union 
(Restoy, 2016). Moreover, some studies have found that cross border M\&As may result in positive efficiency gains (Table 1).

- However, there are a number of obstacles to cross-border M\&As. The relatively small number and frequency of cross-border M\&As has often been explained by the literature with implicit or explicit barriers to the integration of markets. ${ }^{21}$ These could be political and regulatory barriers, as the banking industry is typically considered of strategic importance for the real economy and for financial stability. Certain impediments derive from the incomplete design of the banking union. There has been a tendency of national supervisors to "ring-fence" their banks. There are also several legal aspects that increase the probability of encountering obstacles in their execution (Box 3). But non-political obstacles such as cultural barriers might also be holding back cross country bank M\&As (Buch and DeLong, 2008).

\section{Conclusion}

The results in this paper point to significant heterogeneity within Italian banks in a system that is fragmented. There are a larger number of banks and lower market concentration levels than in most other euro area countries. While some Italian banks have above EU average profitability ratios and lower cost-to-income ratios than the EU average, other parts are lagging far behind. This holds true for both large and small banks. There is a large dispersion within types of banks, with some mutual and popolare banks enjoying healthy levels of profitability and cost efficiency but most others are weak.

\section{Operational efficiency gains are needed to restore large parts of the Italian banking sector to healthy profitability, alongside measures to clean up bank balance sheets. A bottom-up analysis of 386 Italian banks suggests that while profitability improves as the economy recovers, operational efficiency gains are needed to restore large parts of the banking system to healthy profitability. However, even if all banks are able to achieve cost- to-income ratios in line with the EU median, significant parts of the banking sector are still expected to be challenged or weak, indicating that other factors, which are dragging down profitability, such as the high stock of legacy NPL assets, also need to be addressed.}

\section{Banking system consolidation can play a useful role in facilitating such efficiency gains, but should not be seen as a panacea to deal with banking sector problems. It needs to be part of a comprehensive strategy. In Italy, profitability gains cannot come solely from M\&As but other measures are also needed, such as growth-enhancing structural reforms as well as active resolution measures for NPLs. Some large banks also need to rationalize their operations, with UniCredit already starting to take those steps recently with a large capital raising plan and efforts to reduce the stock of NPLs. It remains to be seen whether other banks can follow suit. In light of the mixed experiences with efficiency gains in other}

\footnotetext{
${ }^{21}$ EC (2005) has estimated that between 1999 and 2004, cross-border mergers M\&As accounted for around 20 percent of the total value of M\&As in the financial sector in the EU. Estimates based on data from SnL show that between 2005 and 2016 this ratio was 13 percent for the euro area (see also Figure 4). One well known case was the take-over of the German Bayerische Hypo- und Vereinsbank by Unicredit in 2005.
} 
countries, a careful analysis of the viability of synergies and efficiency improvements is needed for individual cases of M\&As.

Cross-country experience can inform steps to ensure that as many benefits as possible can be reaped from the consolidation process that they have set in train. Experiences from other countries and the literature highlight the importance of enhancing governance and tackling remaining vested interests opposed to efficiency improvements as part of the consolidation process, strengthening supervisory oversight, taking prompt corrective action when needed, and addressing structural rigidities that could limit efficiency gains. There is also a role for policies at the EU level to facilitate a level playing field for crossborder M\&As, which the literature has shown are often more efficiency enhancing than domestic M\&As. 


\section{Box 1. Recent Reforms to Support Banking System Consolidation}

Banche Popolare (BPs, March 2015). Prior to the reform, governance aspects of BPs hindered market diligence and banks' capacity to raise capital from outside sources. BPs, which account for about 14 percent of the banking system, gave equal voting rights to all members (one member-one vote) and imposed restrictions on ownership rights ( 1 percent of capital with larger amounts permitted for institutional investors) as well as limits on proxy voting. These restrictions made it difficult for any shareholder to change the governance structure or replace poorly performing managers. Cooperative ownership restrictions also made it virtually impossible to attract strategic investors, as these did not have a chance of acquiring management control. The March 2015 reform marked a change in the governance structure of BPs with total assets exceeding $€ 8 \mathrm{bn}$. Among other things, the reform removed key structural inefficiencies such as (i) one vote per head and (ii) limitations on the size of individual shareholdings. Banks were granted until end-2016 to transform into joint stock companies. All but two of the 10 BPs have converted into joint stock companies by end-2016. As a result of these reforms, the merger between Banco Popolare and Banca Popolare di Milano was completed in 2016, creating the third largest banking group in Italy However, the reform is currently on hold due to successful challenges in court by dissenting investors.

Mutual banks (BCCs, February 2016). The mutual bank reform requires the smaller cooperative banks (337 as of Q3 2016) to consolidate under joint-stock (holding) companies with at least $€ 1$ billion in equity in 18 months starting November 2016 (the time the secondary legislation was passed). Plans are under development for the consolidation of most BCCs into three cooperative banking groups and the parent companies should be Gruppo Bancario Iccrea, Cassa Centrale Banca and Cassa Centrale Raiffeisen. The parent company will exercise coordination and develop guidelines towards BCCs on the basis of a cohesion agreement. The cohesion contract sets out, among other things, the parent company's powers to direct and coordinate the BCCs belonging to the group, which must be proportional to their risk level as well as the requirements for admission to the group. In the event of a breach of the strategic orientation and operational objectives established by the parent company, the latter may adopt corrective measures and impose sanctions, including removing and replacing the management boards of the BCC and expelling it from the group. BCCs will maintain full autonomy in their relationship with end customers, but there will be common risk management and internal control systems for the assessment, prevention, and monitoring of all risks as well as a cross-guarantee system. ${ }^{2}$

Foundations (April 2015). In Italy, bank ownership by foundations, which are private, non-profit entities that do not have shareholders and are subject to political influence, has raised specific challenges for corporate governance and limited opportunities for domestic and international strategic and financial investors (Jassaud, 2014). In 2014, foundations were major shareholders in 23 percent of Italian banking assets through participations in 20 percent or more of bank capital. Moreover, in several large banks, they controlled bank boards with an even smaller share of ownership, often through shareholders' agreements. The Italian Ministry for the Economy and Finance and the Association of Banking Foundations and Saving Banks in April 2015 signed a protocol setting out self-regulating principles applicable to Italian banking foundations on several issues, including asset management policies and corporate governance. Almost all the existing foundations adhered to the protocol (85 out of 86). The foundations will implement the principles set out in the protocol by amending their by-laws. These principles encompass a wide spectrum of issues, including policies for a prudent asset management, a cap on total indebtedness (i.e., 10 percent of total assets), a ban on the use of derivative instruments (other than those entered into for hedging purposes or without any risk of losses), and corporate governance principles (e.g., required turn-over of management bodies). The protocol will also set a limit on each foundations' exposure towards any single entity or group of entities. In particular, each foundation may not invest, directly or indirectly, more than one-third of its total assets on any single entity or group of entities. Any foundation with investments exceeding the one-third limit as of 22 April 2015 is required to dispose of the excess within the next few years (i.e., three years in the event of listed financial instruments, or five years in the event of non-listed financial instruments). As of 2015, 42 foundations had more than one-third of their assets invested in one bank or banking group (of which 16 are in listed banks and 26 are in non-listed banks) (Cova and others, 2015).

${ }^{2}$ See also Bank of Italy, Financial Stability Report 1/2016. 


\section{Box 2. The Spanish Experience: Consolidation of Savings Banks}

The Spanish banking sector underwent substantial consolidation beginning in 2009. One important component was the consolidation of the savings banks (cajas, SSBs). ${ }^{1}$ Before the crisis there had been 46 SSBs accounting for about half of the financial sector's assets, and by 2016, this number was reduced to 2 through mergers, acquisitions and interventions. A consolidation strategy, aimed at rationalizing the capacity of the SSB system, was pursued. One key measure was the spin-off of SSBs' banking business into newly created commercial banks that operate under the supervision of the Bank of Spain and the Single Supervisory Mechanism (SSM) and are able to raise capital. Fit and proper requirements and conflict-of-interest rules for SSBs governing bodies were strengthened (IMF, 2012, 2014).

Some useful lessons can be learned from the Spanish experience:

- $\quad$ Mergers may not be a solution when entities involved are in difficulties. Initially some mergers of SSBs overburdened by bad loans intensified the problem since the "good cajas" were not good enough, so when they were merged with "bad cajas" the result were weak large entities that did not offer sufficient trust to private investors and had to be bailed out (Otero-Iglesias and others, 2016). A number of mergers that initially took place were also defensive moves by savings banks in the same region as regional governments did not want to lose control over them. All intraregional mergers resulted in entities that had to be taken over, bailed out and later sold off with the state suffering huge losses (Maudos and Vives, 2016).

- Challenge vested interests. There can be important incentives built into the system, which may slow down the process and make it costlier. For instance, in the region of Galicia, there was a lot of political resistance to the merger of two cajas from rival cities followed by long discussions regarding the location of new headquarters. The politics of mergers and acquisitions was so complex that precious time was lost (Otero-Iglesias and others, 2016). Thus, it is vital that the authorities effectively challenge such vested interests that are hindering financial stability and economic efficiency.

- Addressing corporate governance shortcomings is key. Political control of the cajas was one of the problems that led to their subsequent vulnerabilities. As a result of the reforms, fit and proper criteria for SSB themselves have been strengthened (IMF, 2012, 2014). Members of the board of directors of SSBs are now subject to the same general duties applying to directors of commercial companies. Moreover, at least the majority of the board of directors of SSBs need to be independent (for listed companies at least one-third of directors ought to be independent, this is also true for entities that are recapitalized with public money). Recent reforms have significantly improved the governance of SSBs by introducing limits on the maximum size of representatives in the governing bodies of SSBs, which were overburdened with a massive number of stakeholders. Clear incompatibility requirements have been established for politically elected officials.

- $\quad$ Sharing responsibility in supervision can be problematic. This is especially the case when there is political influence and interference at the local level. Before the reforms and the introduction of the SSM, cajas were subject to supervision by the Bank of Spain, but governance aspects were regulated by both the national government and regional governments. This led to issues of blurred competences or uncertainty in the allocation of competences and delaying action. This was changed as part of the reforms, with the Bank of Spain becoming the exclusive supervisor of the newly created commercial banks until the introduction of the SSM.

${ }^{1}$ Spanish savings banks are different from Italian cooperative banks though they share some common features such as their close links to local communities and politicians (Otero-Iglesias and others, 2016). They are closer to Italian foundations in terms of their legal structure. With a few exceptions, savings banks have disappeared in Italy (Bülbül and others, 2013) following their privatization that started in the late 1980s and that resulted in mergers with banks of various types and the creation of large nationally as well as internationally operating banks such as UniCredit and Intesa San Paolo. 
Box 3. Legal Aspects of Cross-Border M\&As in the EU ${ }^{1}$

Cross-border M\&As represent complex legal transactions, involving the application of multiple pieces of legislation. This in turn increases the probabilities of encountering obstacles in their execution.

Although acquisitions achieve the same economic result as mergers (concentration of resources), the legal technique to achieve that result is completely different: in an acquisition, a company acquires shares in another company for a percentage sufficient to provide control. A merger is a transaction that requires the dissolution of at least one of the participating companies, with the transfer of the whole estate of the dissolved company (or companies) to another existing company (merger by absorption) or to a newly created company (merger by creation of a new company).

The choice of the legal technique for an M\&A transaction has important implications: in principle, an acquisition is less complex technically (since it may be based on a straightforward sale of shares), but there can be numerous legal and regulatory issues to consider:

- authorization of the supervisor: a substantial acquisition of shares in a supervised entity requires the authorization of the supervisor. In the cases of credit institutions in the Euro Area, the ECB examines and authorizes the acquisition, in cooperation with the national bank supervisor.

- competition: depending on the size of the concentration and its effects on the relevant market, national and European competition authorities can establish conditions for the acquisition, or even block it.

- securities regulation: if the acquisition is of a listed company, it will be necessary to launch a takeover bid, with the authorization of the competent securities regulator and compliance with all the necessary requirements, including a prospectus.

- hostile acquisitions: when the acquisition of the listed company is not based in an agreement with controlling shareholders, there will be a hostile takeover bid. There are multiple barriers to these bids in different countries of the European Union (for instance, multiple voting rights of shares; staggered boards; pyramidal structures), and the target company can use these defenses to defeat the bid or to force the bidder to raise the price.

To address uncertainties about cross-border mergers of companies, the EU adopted the Directive for cross-border mergers of limited liability companies (Directive 20005/56/EC). This Directive sets general principles for the execution of cross-border mergers, establishing that each company participating in the merger is subject to its own national merger rules. This has created some uncertainties, because the national regimes are not fully harmonized (for instance, the rules for the protection of creditors in mergers present differences across member states).

The Directive also applies to financial institutions. However, the Directive recognized the possibility for national authorities to block mergers. Italy is one of the countries that, in implementing the Directive, allowed the national authorities, including the Bank of Italy, to block mergers affecting their supervised entities. With the establishment of the cooperation framework between the ECB and the national authorities within the SSM (framework regulation (SSM framework regulation, ECB/2014/17), it is noticeable that there is no express mention to mergers in the text but, since a merger will normally imply either a significant acquisition or the creation of a new entity, in both cases it will be the ECB who will have the competence to authorize, in cooperation with the national supervisor.

Cross-border mergers raise the same issues regarding competition law as acquisitions. In the area of securities regulation, a merger may require a capital increase in a listed company, and a de-listing of the absorbed company. There are additional factors to be considered, especially worker participation and protection rules, and the tax regime.

The factors listed above can give an idea of the complexity of cross-border mergers, especially those affecting financial institutions. In addition, it is necessary to consider that the costs of these transactions can be very substantial. Finally, a factor that has special importance in the banking sector is the fact that there may be different corporate structures for credit institutions (banks, companies, credit cooperatives, and other figures). When a merger involves credit institutions of different nature (heterogeneous mergers), there are additional complications, since the merger will determine, at least for one of the participating entities, a fundamental change in the structure of the institution and the rights of shareholders/members.

\footnotetext{
${ }^{1}$ Prepared by Jose Garrido, International Monetary Fund, jgarrido@imf.org.
} 


\begin{tabular}{|c|c|c|c|}
\hline & Efficiency & $\begin{array}{c}\text { Competition and Financial } \\
\text { Stability }\end{array}$ & Credit flows \\
\hline $\begin{array}{l}\text { Theoretical } \\
\text { considerations }\end{array}$ & $\begin{array}{l}\text { Pros: M\&As can allow banks to exploit economies of scale } \\
\text { and scope, generate cost savings and higher profits. } \\
\text { Cons: Larger and more diversified firms are not necessarily } \\
\text { run more efficiently, M\&As may not be done for efficiency } \\
\text { reasons but because of different motivations (e.g., empire } \\
\text { building for executives). }\end{array}$ & $\begin{array}{l}\text { Pros: Large banks can diversify better, } \\
\text { earn higher profits, and can be } \\
\text { monitored by regulatory agencies more } \\
\text { easily. } \\
\text { Cons: M\&As can increase the market } \\
\text { power of financial institutions, thus } \\
\text { leading to prices above (and volumes } \\
\text { below) those prevailing in a hypothetical } \\
\text { situation of perfect competition. } \\
\text { More concentrated system creates } \\
\text { institutions that may be "too big to fail" } \\
\text { and result in moral hazard issues. }\end{array}$ & $\begin{array}{l}\text { If M\&As involve small banks, then the } \\
\text { consolidation process may affect availability } \\
\text { of credit to small firms relying traditionally } \\
\text { on bank credit }\end{array}$ \\
\hline $\begin{array}{l}\text { Empirical } \\
\text { Evidence }\end{array}$ & $\begin{array}{l}\text { Scale economies: For the smallest banks, there are scale } \\
\text { economies that allow average costs to fall with increases in } \\
\text { bank size, but they account for less than } 5 \text { percent of costs. } \\
\text { For larger banks, constant average costs or slight } \\
\text { diseconomies of scale prevail. Scope economies: There are at } \\
\text { most relatively minor scope economies that reduce cost by } \\
5 \text { percent or less when multiple products are produced jointly. } \\
\text { Revenues appear to be unaffected by product mix (Berger } \\
\text { and Humphrey, 1994). Some studies find that cross-border } \\
\text { acquisitions are associated with a reduction in the costs of the } \\
\text { target, while no significant effect is found for domestic } \\
\text { M\&As. Many studies argue that difficulties in improving cost } \\
\text { efficiency are related to the obstacles encountered to reducing } \\
\text { banks' labor forces (BIS, 2001). } \\
\text { Japan: Evidence for Japan that looks across different types of } \\
\text { M\&As, finds positive effects on efficiency among mutual } \\
\text { banks but less clear on mergers within overall system } \\
\text { (Montgomerya, Harimayab, and Takahashic, 2014). } \\
\text { Italy: Literature seems to suggest that consolidation wave } \\
\text { in } 1990 \text { s led to efficiency gains but resulted in complicated } \\
\text { ownership structure and governance problems with dense } \\
\text { web of cross- shareholdings (Mezzori, 2002). }\end{array}$ & $\begin{array}{l}\text { There are many theoretical papers on } \\
\text { this topic, but the empirical evidence is } \\
\text { relatively scarce. Some recent studies } \\
\text { find that crises are less likely in more } \\
\text { concentrated banking systems, even } \\
\text { after controlling for a wide array of } \\
\text { macroeconomic, regulatory, and } \\
\text { institutional factors (e.g., Beck, } \\
\text { Demirguc-Kunt, and Levine, 2006). }\end{array}$ & $\begin{array}{l}\text { Several studies find that banks involved in } \\
\text { mergers tend to reduce their portfolio share } \\
\text { of small business loans (Berger, Demsetz, } \\
\text { and Strahan, 1999). However, short-run } \\
\text { shocks to credit due to consolidation tend to } \\
\text { be absorbed at the market level after some } \\
\text { time (e.g., Berger and others, 1998). } \\
\text { Bonaccorsi di Patti and Gobbi (2007) } \\
\text { analyze the impact of mergers on credit } \\
\text { availability in Italy using micro-level data on } \\
\text { firm-bank relationships. They find that firms } \\
\text { borrowing from a bank involved in a merger } \\
\text { as a bidder or as a target experience a } \\
\text { temporary reduction in credit of } \\
\text { approximately } 1.5 \text { percent and } 2.0 \text { percent, } \\
\text { respectively. The negative shock is absorbed } \\
\text { after three years. }\end{array}$ \\
\hline
\end{tabular}




\section{Appendix}

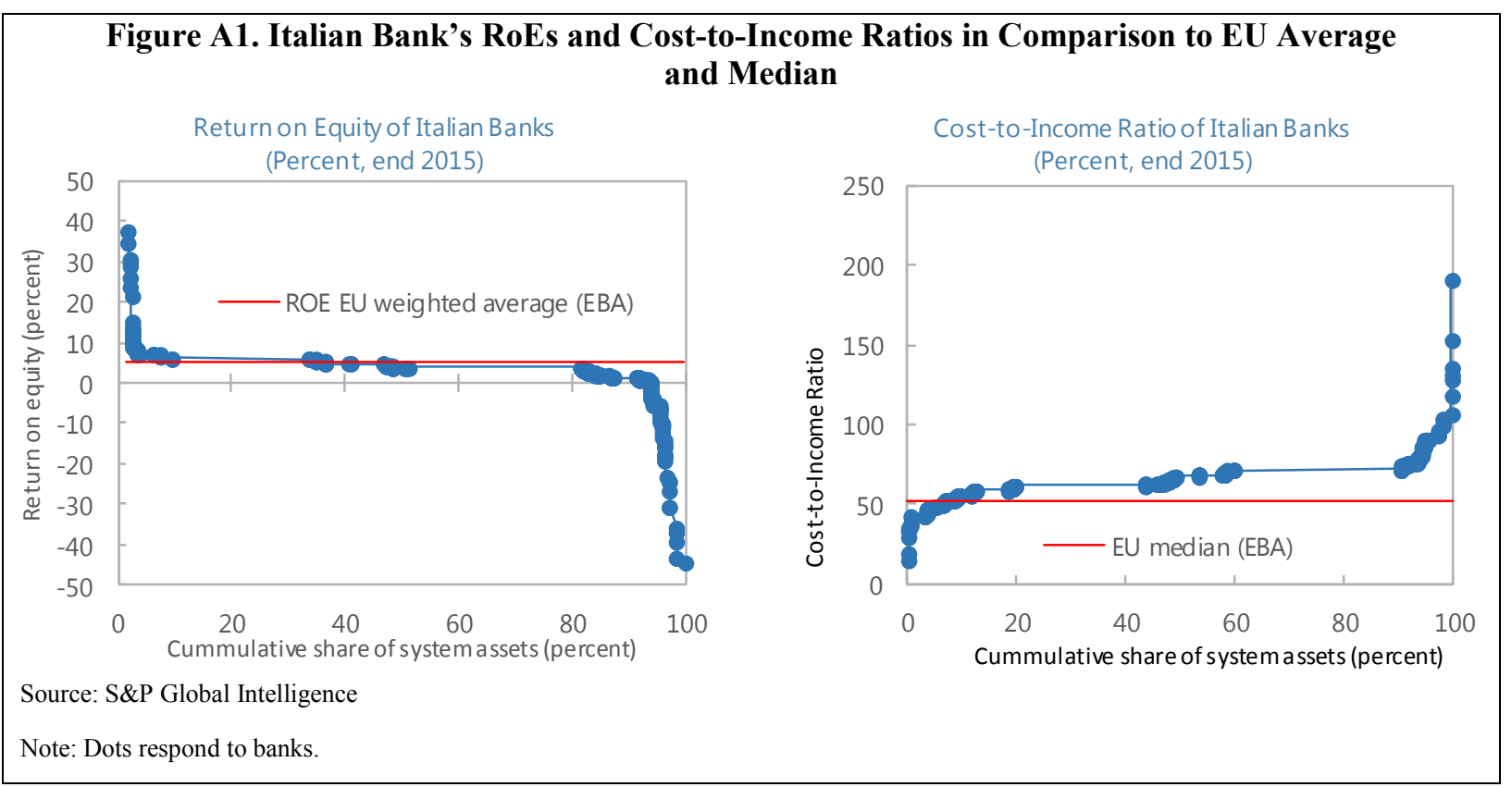




\section{References}

Albertazzi U., Notarpietro A., and S. Siviero, 2016, An Inquiry into the Determinants of the Profitability of Italian Banks, Bank of Italy Occasional Papers No. 364 (Italy: Bank of Italy).

Amel. D., Barnes, C., Panetta, F., and Salleo, C., 2002, "Consolidation and Efficiency in the Financial Sector: A Review of the International Evidence," Federal Reserve Working Paper, 2002/47.

Bank for International Settlements, 2001, "The Effects of Consolidation on Efficiency, Competition and Credit Flows," Group of Ten-Consolidation in the Financial Sector, Chapter 5.

Bank of Italy, 2016, "Italy's Less Significant Banks: General Overview and Supervision," Supervisory Note.

Beck, T., Demirgüc-Kunt, A., Levine, R., 2006, "Bank Concentration, Competition and Crises: First Results,” Journal of Banking and Finance, Vol. 30, pp. 1581-1603.

Berger, A. N., and Humphrey, D., 1994, "Bank Scale Economies, Mergers, Concentration, and Efficiency: The U.S. Experience," Wharton School Center for Financial Institutions Working Paper, 94-25.

Berger, A. N., A. Saunders, J. M. Scalise, and G. F. Udell, 1998, "The Effects of Bank Mergers and Acquisitions on Small Business Lending," Journal of Financial Economics, Vol. 50, pp. 187-229.

Berger, A. N., R. E. Demsetz, and P. E. Strahan, 1999, "The Consolidation of the Financial Services Industry: Causes, Consequences, and Implications for the Future," Journal of Banking and Finance, Vol. 23, pp. 135-194.

Bonaccorsi Di Patti, E. and G. Gobbi, 2007, "Winners or Losers? The Effects of Banking Consolidation on Corporate Borrowers," Journal of Finance, Vol. 62, pp. 669-695.

Buch, C., and G.L. DeLong, 2008, "Banking Globalization: International Consolidation and Mergers in Banking," IAW Discussion Paper, 28/2008.

Bülbül, D., Schmidt R.H., and U. Schüwer, 2013, "Savings Banks and Cooperative Banks in Europe," SAFE Policy Paper Series No. 5.

Carretta A., Farina V., Gon, A., and A. Parisi, 2011, "Politicians on Board! Do Political Connections Affect Banking Activities in Italy?” MPRA Paper No. 33549. 
Cetorelli, N., and M. Gambera, 2001, "Banking Market Structure, Financial Dependence, and Growth: International Evidence from Industry Data," Journal of Finance, Vol. 106 (2), pp. $617-48$.

Cova, B., Braccioni, P., and F. Acerbi, 2015, "A New Milestone in the Revolution of the Italian Banking Sector: The Reform of Banking Foundations,” Paul Hastings Note (May).

Elliott, J., Hoyle, H., and A. Jobst, 2016, "Impact of Low and Negative Rates on Banks [Box 1.3]," in Chapter I: Potent Policies for A Successful Normalization, Global Financial Stability Report, Monetary, and Capital Markets Department, World Economic and Financial Surveys, April (Washington: International Monetary Fund).

European Commission, 2005, "Obstacles to Cross-Border Mergers and Acquisitions in the Financial Sector,” Background Paper, DG Internal Market and Services (April).

Garrido, J., 2016, “Insolvency and Enforcement Reforms in Italy,” IMF Working Paper No. 16/134 (Washington: International Monetary Fund).

— Kopp, E., and A. Weber, 2016, "Cleaning-up Bank Balance Sheets: Economic, Legal, and Supervisory Measures for Italy,” IMF Working Paper No. 16/135 (Washington:

International Monetary Fund).

Infante, L., and M. Piazza, 2014, "Political Connections and Preferential Lending at Local Level: Some Evidence from the Italian Credit Market," Journal of Corporate Finance, Vol. 29, pp. 246-262.

International Monetary Fund, 2017, Global Financial Stability Report (April).

_2016, Global Financial Stability Report (October).

— 2014, "Spain, Financial Sector Reform. Final Progress Report," IMF Country Report No. 14/59 (Washington).

— 2012, "Spain, The Reform of Spanish Savings Banks Technical Notes," IMF Country Report No. 12/141 (Washington).

Jassaud, N., 2014, "Reforming the Corporate Governance of Italian Banks," IMF WP/14/181 (Washington: International Monetary Fund).

Jobst, A. and A. Weber, 2016, "Profitability and Balance Sheet Repair of Italian Banks," IMF Working Paper 16/175 (Washington: International Monetary Fund). 
Koehler, Matthias, 2009, "Merger Control as Barrier to EU Banking Market Integration," ZEW Discussion Paper 07-082.

Kok, C., Móré, C. and Pancaro, C., 2015, "Bank Profitability Challenges in Euro Area Banks: The Role of Cyclical and Structural Factors," Financial Stability Review, ECB (May).

Maudos J., and X. Vives, 2016, "Banking in Spain," mimeo, University of Valencia and IESE Business School.

Mezzori, M., 2002, "Consolidation, Ownership Structure and Efficiency in the Italian Banking System,” BNL Quarterly Review, 221, pp. 177-217.

Ministry of Economy and Finance (MEF), 2016, Italian Banking Sector: Recent Developments and Reforms (Italy).

Mohaddes, K., Raissi, M., and A. Weber, 2017, "Can Italy Grow Out of Its NPL Overhang? A Panel Threshold Analysis,” IMF Working Paper 17/66 (Washington: International Monetary Fund).

Montgomerya, H., Harimayab, K., and Y. Takahashic, 2014, "Too Big to Succeed? Banking Sector Consolidation and Efficiency," International Financial Markets, Institutions and Money Vol. 32, pp. 86-106.

Otero-Iglesias, M., Royo S., and F. Steinberg, 2016, “The Spanish Financial Crisis: Lessons for the European Banking Union,” Real Instituto Elcano.

Restoy, F., 2016, "European Banking Sector-Situation and Challenges," speech delivered at the UIMP seminar organized by the APIE (Association of Economics Journalists), Madrid, June 17. 